\title{
Big Challenges by a Small Microfinance Institution- A Case Study of SafeSave Bangladesh from the Customer Satisfaction and ICT Introduction Perspective
}

\author{
Mohammad Thoufiqul Islam ${ }^{1}$, Chikako Takanashi ${ }^{1} \&$ Takashi Natori ${ }^{1}$ \\ ${ }^{1}$ Ritsumeikan University, Kyoto, Japan \\ Correspondence: Mohammad Thoufiqul Islam, Ritsumeikan University, Kyoto, Japan. E-mail: \\ gr0085pv@ed.ritsumei.ac.jp
}

Received: March 10, 2013 Accepted: May 23, 2013 Online Published: June 18, 2013

doi:10.5539/ijbm.v8n14p23 URL: http://dx.doi.org/10.5539/ijbm.v8n14p23

\begin{abstract}
Bangladesh is considered as a birthplace of modern microfinance movement. This movement has mainly been instigated by the various microfinance institutions irrespective of their size. This paper focuses on such an innovative microfinance institution namely SafeSave (SS). SS is definitely unique in that they have adopted information and communication technologies (ICT) and built competence in dealing with vulnerable slum dwellers as a client even though they are a small firm in the market. This study compared the operational uniqueness and performance of SS among large MFIs equipped with ICT and small MFIs without ICT experience. In this context statistical analysis such as unpaired t-test and regression analysis were conducted. Customer satisfaction of SS was higher than other types of MFIs which showed the important lesson for small MFIs without ICT experience. Even though SS is innovative, there are scope to improve the operational mechanism by better management and more efficient information and communication technologies.
\end{abstract}

Keywords: microfinance, information and communication technologies, women empowerment, socio-economic development, financial institutions

\section{Introduction}

\subsection{Background of the Study and Introduction of the Research Question}

As a pioneer in microfinance (MF), Bangladesh achieved remarkable success in socio-economic progress. Grameen Bank (GB), one of the major microfinance institutions (MFIs), was nominated and attained the Nobel Peace Prize in 2006. Apart from the contribution of GB, there are some other major MFIs operating in all 64 districts of Bangladesh such as Bangladesh Rehabilitation Assistance Committee (BRAC), ASA and Proshika. According to the report of Microcredit Regulatory Authority (MRA), Bangladesh, very large MFIs are serving 22.49 million clients which are around $83 \%$ of total market share and the rest is in the small or very small category of which 92 percent is NGO-MFIs (Microcredit Regulatory Authority, 2010). These small and very small MFIs are equally credit worthy for the success of MF establishment in Bangladesh.

MF industry in Bangladesh has been passing through the maturity stage. Due to the high imitation effect, people of Bangladesh adopted MF (Islam and Natori, 2012). All the firms regardless of their size are experiencing the competition extensively. At this competition, small firms are facing similar challenges like big firms. This study will address some of the big challenges like how to deal with the client satisfaction issue and technology adoption issues of a small firm by presenting SS Bangladesh case study.

Furthermore, comparing to formal financial organization, MFIs are dealing with a different set of problems or challenges. MF targets mostly the poor community who do not have enough financial solvency or asset to pay as collateral against loans. Moreover they are less educated. Dealing with such a client is really a big challenge for any MFIs especially as an informal financial institution. Earlier stage in MF industry, MFIs could get funds from various charitable or non-charitable organizations as a loan or grant (Ahmed, 2009). But in due course of time, almost all the MFIs have mostly been depending on their own source of funds. Now in many cases self fund or funds from client's savings are major source of fund for lending purposes. And as a common practice, most of the MFIs do not have any collateral system against loans. Instead, MFIs are practicing sense of group influence to minimize the risks of repayment. Increasing outreach, retaining existing clients, increasing the savings base, 
and managing the operation in efficient manner are some of those steps. They are not only dealing with funds but also with human (clients are interchangeably used as human). So, securing and managing fund is big challenge. At the same time distributing to the poor is another crucial matter (Dowla and Alamgir, 2003).

Comparing to the big MFIs like GB, small MFIs do not have enough resources and experiences to deal with the big challenges mentioned above. So tackling those obstacles and building positive image is a rare phenomenon and achievement for small MFIs. In this context, this case study on SS Bangladesh will contribute to show the operational innovative mechanism.

There are certain distinct merits of this study. Firstly, it attempts to investigate a customer satisfaction aspect which is essential for sustainability of this industry. Secondly, it explores underlined issues of ICT prospects in MF industry. Thirdly, it intends to compare customer feedbacks among large MFIs equipped with ICT, small MFIs without ICT experience and a small MFI utilizing ICT. SafesSave Bangladesh falls into the last group. The main research question of this study is how a small MFI namely SS Bangladesh is dealing with customer's expectations and ICT usage.

In the following sections, corresponding literature, methodology, result and discussion included in a sequential manner. Corresponding literature incorporates literature on microfinance, customer satisfaction and ICT. A detailed methodology section includes demographic profile of the sample organizations. Later, case study presents with empirical findings which followed by discussion and conclusion.

\subsection{Literature Review}

As a newly emerged financial social innovation, MF draws attractions by the various researchers. Some researchers address external matters around MF such as impact of employment, poverty, women empowerment and social development. Other researchers incorporate their analysis based on internal matters such as product, process, and service of MF business.

On the macroeconomic aspects, for example, impact of MF on poverty had been studied by various researches around the world (Amin, Becker and Bayes (1998); Khandker and World Bank (1998); Mosely and Hulme (1998)). Similarly, some researches carried on their studies on gender participation in MF programs (Afrin, Islam and Ahmed (2008); Godquin (2004); Goetz and Gupta (1996); Hashemi and Riley (1996); Hashemi, Schuler, and Ann. (1996); Pitt and Khandker (1998); Schuler and Hashemi (1994); Schuler, Hashemi, and Riley (1997); Schuler, Hashemi, and Badal (1998)). With Bangladesh at the center of the research, Ahmed (2009) pointed out the achievements and challenges of MFIs in Bangladesh and highlighted the issues such as the present inefficient mechanism of channeling fund, high rate of fund, target wider group, widening new financial technologies, ensuring the good governance, monitoring purpose of loan and necessity of large loan size on the industry level.

On the microeconomic aspect, Bhatt and Tang (2001) pointed MF business in Bangladesh is passing maturity stage and customer-friendly services are essential for the sustainability of the business but thereafter few detailed research on customer satisfaction in MF in Bangladesh appears. Murray and Lynch (2003) surveyed on customer satisfaction but considered only one organization as a sample in Bangladesh. Therefore, further research is needed in MF in Bangladesh from the customer satisfaction perspective. As customers are major party in the MF business process, so their views and satisfaction should be considered as a priority basis. Customer satisfaction is described as the psychological state of the adopter which can be negative, positive or neutral (Bhattacherjee, 2001; Lendrevie and Lindon, 1997; Verhoef, 2003). Thus, customer satisfaction can be defined as a mind state that guides towards purchasing, repurchase and switching decisions concerning to any products or services.

Although in other countries in Africa and Asia, customer satisfaction analyses in MF have been done from various focuses; costs and price (Cull, Demirgüç-Kunt, Morduch, 2009), responsiveness (Parasuraman, Zeithaml, and Berry, 1985; Avkiran1994, conditions (Mersland, Strom 2009), human relation (Othman, Owen 2001), reliability (Parasuraman, Zeithaml, and Berry, 1985; Avkiran, 1994) and tangibles (Parasuraman, Zeithaml, and Berry, 1985). In addition, concrete variables in customer satisfaction analysis in MF are developed by previous researchers; interest on loan (Lapenu, Pierret 2006), loan disbursement time (Murray, Lynch 2003), time flexibility on installment (Wenham 2004), saving not as a collateral (Menkhoff, Neuberger, Rungruxsirivorn 2012), monitoring loan purposes (Ahmed, 2009), understanding terms and conditions, pleasant staff behavior (Othman, Owen 2001), and mobile money transfer (Au, Kauffman 2008). But they are too fragmented to capture the whole scenario of MF business in Bangladesh. Therefore, this research will incorporate these enriched achievements to develop the holistic analytical framework.

About the ICT usage, many scholars point its usefulness. It can be helpful for remote operations and financial security (Diniz et al. 2008, 2011). ICT can also positively empower even a small firm to be effective in their 
operation (Attali 2000; Beck, DemirgucKunt, and Honohan 2009; Lee, Kim, Choi and Lee 2009). It can reduce the transaction cost and improve efficiency which is proved by the extensive use of ICT by banks and other financial institutions (Chang 2002; Hannan and McDowell 1984; Haynes and Thompson 2000). With the help of handheld devices such as mobile, smart phones or personal digital assistance (PDA) staffs of a MFI can easily authorize loan proposal of a client and security authentication can be also completed by the same process(Silva, 2002). Concerning ICT usage, Kauffman and Riggins (2012) emphasized on maturing the MF and how client-centered MF can be established by the ICT.

In spite of the magnitude of ICT in operational and functional efficinecy level, it is by far in immature stage in the MF industry (Dailey 2005). It is rational to assume that in the developing countries, where energy, infrastructure and other crucial problems exists, establishing a ICT based model is rather a more critical tasks (Keniston, 2003).

Previous literatures did not explore the interlinkage matters between ICT and customer satisfaction. Most of the researches pointed out the importance of either ICT for MF or customer satisfaction for microfinance. This study will attempt to fill out the gap of unexplored interconnectivity between ICT and customer satisfaction for betterment of MF business.

\section{Method}

This study started with a pilot study of 35 clients selected at a random basis from four different districts in Bangladesh to understand the situation of MF in Bangladesh and verify the major factors that affects customer satisfactions. The primary method of communication in the pilot study was face to face conversation with the clients in their house. Each respondent was interviewed around 1 hour and 30 minutes. In the pilot study process, this study also interviewed 4 organizational managers and 4 experts in the MF field. Responses were analyzed through statistical, literature and with subsequent views of experts.

We selected major 10 variables under six broad categories through literature reviews and pilot study. The details of these are reporting in the table 1(Italic means our variables).

Table 1. Variables at a glance

\begin{tabular}{lll}
\hline \multicolumn{2}{c}{ Categorization } & Variables name under each categories \\
\hline Independent & Costs and Price & Loan amount flexibility (LAF), Interest on loan (IOL) \\
Variables & Responsiveness & Loan disbursement time (LDT), Time flexibility on installment (TFI) \\
& Conditions & Saving not as a collateral (SAC), Monitoring loan purposes (MLP) \\
& Human Relation & Understanding terms and conditions (UTC), Pleasant staff behavior (PSB) \\
Reliability & Faith on recording (FOR) \\
& Tangibles & Mobile money transfer (MMT) \\
\hline Dependent Variable & Customer satisfaction (CS) \\
\hline
\end{tabular}

\subsection{Model Proposition}

Based on the above variables, this study proposes the following model for assessing the customer satisfaction.

$$
C S=B_{0}+\alpha^{\prime} C N P+\beta^{\prime} R E S+\gamma^{\prime} C O N+\eta H R+\mu R E L+v T A N+\varepsilon
$$

Where CS stands for the customer satisfaction of respondents on the services of MFI; $\alpha, \beta, \gamma, \eta, \mu$ and $v$ stands for the vectors of coefficients to be estimated for the six categories of variables; namely costs and price (CNP), responsiveness (RES), condition (CON), human relation (HR), reliability (REL) and tangibles (TAN). The variables under each category have been presented in the table 1 .

\subsection{Main Survey}

This study has two aims; I. Find out the factors of customer satisfaction and compare among different type of MFIs, and II. Investigate the challenges of SS in their MF business operations.

This study conducted survey, in-depth interview, and observation of field operation on ICT usage of MFI.

Survey was conducted on 226 clients of SS Bangladesh to find out the factors of customer satisfaction and compare among large MFIs, Small MFIs and SS. Survey on the clients of SS was taken in to 3 separate slums in Dhaka city, Bangladesh. 
Specifically for this study, we have conducted customer satisfaction survey on the clients of SS and other four MFI's responses with the structured questionnaire. This study considers five point likert scale questionnaire in this regard. Details of the data collection summary are available in table 2. Another questionnaire was used to get organizational information about their ICT usage, process and views. This ICT-questionnaire were completed by the 5 MFIs ( BRAC and ASA as a two large MFIs with ICT competence, Polli Sheba Songsha and Oriental Foundation as a small MFIs without having ICT orientation and SS as a small but ICT adopter in field level operation).

5 in-depth interviews of organizational staffs were conducted in due purposes. For this study, we also visited three times various slums of Dhaka city, Bangladesh where SS operated in November, 2011, March, 2012 and August, 2012 to observe the field operations, ICT usage and clients' views regarding the ICT and other factors. This study was conducted unpaired t-test and regression analysis to achieve the aim of this paper. SPSS has been used as an analytical tool in this regard.

Table 2. Survey details of customers in different MFIs in Bangladesh

\begin{tabular}{lcc}
\hline Name of MFIs & Number of clients surveyed & Locations (Districts in Bangladesh) \\
\hline SafeSave & 226 & $\begin{array}{c}\text { Mohammadpur, mirpur and Gonoktuli in Dhaka } \\
\text { Comilla, Chittagong, Gopalgonj, Feni, Sylhet, } \\
\text { Kustia, Naogaon. }\end{array}$ \\
ASA & 148 & $\begin{array}{c}\text { Comilla, Gopalgonj, Jessore, Netrokona, } \\
\text { Lalmonirhut, Khulna, Barisal }\end{array}$ \\
$\begin{array}{l}\text { Polli Sheba Songsha } \\
\text { Oriental Foundation }\end{array}$ & 71 & Bhola \\
& 74 & Bagerhut, Khulna \\
\hline
\end{tabular}

\subsection{Demographic Characteristics}

Data have been analyzed with the help of various statistical tools such as descriptive statistics and regression. SafeSave (SS), ASA-BRAC (AB), and Oriental Foundation and Polli Sheba Songsha (OF-PSS) clients profile can be explained by the respondent's demographic profile.

Table 3. Demographic profile of the selected MFIs

\begin{tabular}{|c|c|c|c|c|}
\hline \multicolumn{2}{|c|}{ Demographic indicators (data in \%) } & SS & $\mathrm{AB}$ & OF-PSS \\
\hline \multirow[t]{3}{*}{ Age } & 18 to 30 & 38 & 26 & 33 \\
\hline & 30 to 50 & 53 & 67 & 63 \\
\hline & 50 and above & 9 & 7 & 4 \\
\hline \multirow[t]{2}{*}{ Gender } & Female & 48 & 84 & 45 \\
\hline & Male & 52 & 16 & 55 \\
\hline \multirow[t]{5}{*}{ Education } & Illiterate & 14 & 14 & 8 \\
\hline & Illiterate with signing capability & 32 & 38 & 46 \\
\hline & Primary & 23 & 40 & 29 \\
\hline & Secondary & 29 & 8 & 15 \\
\hline & University & 2 & & 2 \\
\hline \multirow[t]{4}{*}{ No of Family member } & Less than 2 & 2 & 3 & 2 \\
\hline & 2 to 4 & 51 & 51 & 46 \\
\hline & $5-8$ & 43 & 41 & 48 \\
\hline & 8 and more & 4 & 5 & 4 \\
\hline \multirow{4}{*}{$\begin{array}{l}\text { Average monthly Income in } \\
\text { USD }\end{array}$} & Less than $\$ 25$ & 8 & 11 & 20 \\
\hline & $\$ 25$ to $\$ 61$ & 6 & 38 & 9 \\
\hline & $\$ 61$ to $\$ 122$ & 48 & 31 & 38 \\
\hline & $\$ 122$ and more & 38 & 20 & 33 \\
\hline
\end{tabular}


More than $50 \%$ clients of SS belong to age of 30 to 50 reported from table 3 . About $46 \%$ are illiterate, some of them having capability to signature their name. While discussing with clients, this study reveals that most of the clients get help from other to calculate their balance in their passbook. $65 \%$ female respondents informed that their husband is the house head. Only $7 \%$ are head of their own family. Head of the family usually makes major decisions. More than $67 \%$ respondents own television and mobile at their house. Around 37\% respondents are involved in small business. Altogether $72 \%$ respondents are engaged in small business whose average monthly income is around $\$ 61$ and more. Respondents whose occupations are day laborers, wage workers in garments, rickshaw pullers earn mostly $\$ 61$ to $\$ 122$ per month.

Respondents of ABs are mostly women (84\%) and belong to age group 30- 50. Their monthly income $(69 \%)$ is within $\$ 25$ to $\$ 122$. As an occupation, $46 \%$ respondents involved in agriculture and $40 \%$ have small business. Regarding technology orientation, $40 \%$ respondent said they have television and mobile phone at their home. $62 \%$ female respondents said husband is the house head, only $16 \%$ said they are house head.

In the small MFIs such as OF-PSS, the percentage of women clients is around 45 . Out of total client, $54 \%$ are illiterate. $71 \%$ respondents average monthly income more than $\$ 61$. Around $41 \%$ involved in agriculture and $21 \%$ in small business. $54 \%$ have mobile at their home. $91 \%$ female respondents said husband is the house head.

\section{The SafeSave Case Study}

SafeSave is a microfinance institution working under the registration as a cooperative organization. SS is a small MFI under the classification of MRA, Bangladesh. It started their business on 1996 and targeted nine low-income slum areas in Dhaka city, Bangladesh. Dhaka is the capital of Bangladesh where estimated population is more than 14.6 million within 1463.60 square kilometers (565 square meters). Dhaka is overly populated city with many slums. Mostly people of low income are living in those slum areas. These people are most vulnerable in the sense of resident status. They are staying there as a temporary basis. SS targets this underprivileged group. So while selecting a MFI, this study considered following criterions such as low-income people, small in terms of outreach, having experience of innovative field operation with ICT, unique product features, and location. SS has been selected because of their characteristics of low-income clients, location on slum areas, number of clients (18200 clients), use of PDA in field transaction, and unique product feature such as savings capacity as small as 2 cent (US) at a flexible time period. Primary occupations of the SS clients' are housemaids, day-laborers, rickshaw drivers, self-employed as small stall-holders, peddlers or dressmakers, some have waged jobs in the garments industry and others are elderly, unemployed or schoolchildren.

\subsection{Performance of SafeSave Comparing to the Other Types of MFIs}

\subsubsection{Customer Satisfaction}

Customers are considered as the lifeblood of any business. Success mostly depends on the satisfaction level of customers. In comparison of customer satisfaction, SS is better performer. From the unpaired t-test, the mean values of SS, Large MFIs with ICT and Small MFIs without ICT are 3.67, 3.64 and 3.47 respectively(Table 4). In the comparison of SS and small MFIs without ICT, mean differences have proven significant as well. Thus, SS have considerable credentials on achieving such responses from the clients despite their organizational size.

Table 4. Unpaired t-test on customer satisfaction between SS and small MFIs without ICT, and between SafeSave and large MFI with ICT

\begin{tabular}{lcccc}
\hline & $\mathrm{N}$ & Mean & Std. Deviation & Std. Error Mean \\
\hline Large MFIs with ICT & 252 & 3.64 & .969 & .061 \\
SafeSave & 227 & 3.67 & .931 & .062 \\
Small MFIs without ICT & 109 & 3.47 & .958 & .092 \\
\hline
\end{tabular}

The following discussion will explain about the influencing factors of customer satisfaction. The comparative performance of SS with other types of MFIs can be explained by the regression results of each category.

It is mentionable that all the different groups of MFIs in this study are examined under the same regression model due to the comparison purposes. The regression results of table 4 shows that the overall model fit for large MFIs with ICT, Small MFIs without ICT and SS with $\mathrm{R}^{\wedge} 2=0.34,0.33$ and 0.29 respectively.

The ANOVA output indicates that there was a significant effect of independents variables on customer 
satisfaction which can be proven significant at 1 percent level comparing to the $\mathrm{F}$ values in all the above models (table 5).

In comparison of variables that affects to the customer satisfaction, IOL and SAC are proven significant in all three types of MFIs. But variables such as LAF, LDT, TFI, FOR are significant by the responses of clients of SS which is insignificant for the small MFIs without ICT case. Only human relation factors were proven significant in small MFIs without ICT. While comparing with Large MFIs with ICT and SS with ICT, MMT and MLP variables have proven significant in large MFIs case. On the other hand, the variable namely TFI has proven significant in SS case. The result resembles large MFIs with ICT exploits various aspects towards customer satisfaction comparing to small MFIs and SS. At the same time, customers of SS have various influencing factors comparing to small MFIs without ICT experience.

The details statistical outcome has been presented in the table 5 accordingly. The results resembles that ICT has direct effect on various customer satisfaction aspects. MFIs without ICT are advantages in human relation aspects due to high level of human interaction in various steps of operation comparing to MFIs with ICT.

Table 5. Regression estimation values among different sizes of MFIs is Bangladesh

\begin{tabular}{|c|c|c|c|c|}
\hline Category name & Variables name & $\begin{array}{c}\text { ASA \& BRAC } \\
\text { (Large MFIs with } \\
\text { ICT) }\end{array}$ & $\begin{array}{c}\text { PSS \& OF } \\
\text { (Small MFIs } \\
\text { without ICT) }\end{array}$ & $\begin{array}{l}\text { SS (Small } \\
\text { MFIs with } \\
\text { ICT) }\end{array}$ \\
\hline \multirow[t]{2}{*}{ Cost and Price } & Loan amount is flexible & $0.104 * *$ & -.026 & $.149^{* * *}$ \\
\hline & Installment flexibility & 0.171 & -.132 & $.252 * * *$ \\
\hline \multirow[t]{2}{*}{ Responsiveness } & Loan disbursement time & $0.145^{* *}$ & .015 & $.115^{*}$ \\
\hline & Interest on loan & $0.2 * * *$ & $.235^{* * * *}$ & $.109 * *$ \\
\hline \multirow[t]{2}{*}{ Conditions } & Purpose of the loan is monitored & $0.139 * *$ & .185 & .012 \\
\hline & Savings not as a collateral & $0.15 * *$ & $.205^{* *}$ & $.181 * * *$ \\
\hline \multirow[t]{2}{*}{ Human Relation } & Understanding terms and condition & 0.02 & $.196^{*}$ & .045 \\
\hline & Pleasant Staff behavior & 0.079 & $.335 * *$ & .105 \\
\hline Reliability & Faith on Recording & $0.277 * * *$ & -.119 & $.371^{* * *}$ \\
\hline Tangibles & Mobile money transfer & $0.089^{*}$ & .088 & .053 \\
\hline & $\mathrm{R}^{2}$ & .345 & .331 & .289 \\
\hline & F statistics & $20.90 * * *$ & $6.529 * * *$ & $8.789 * * *$ \\
\hline
\end{tabular}

***,*** represents significance at $1 \%, 5 \%$ and $10 \%$ level.

\subsubsection{Efficiency Comparison}

In this section, a comparative study will show to indicate SafeSave's competitive advantage over the other MFIs we selected as sample. Further explanation will be produced to give certain hints for the development of such small MFIs which are facing similar kind of challenges.

MFIs are facing challenges in getting fund from donor as a grant and loan. So it is important to establish self fund based on savings based. The more number of savings clients', the more chances to build a strong financial-base. If a firm has more financial base, then loan disbursement will be higher. Average loan per client can be comparison indicator by which we can find competitive advantage of one another. MF industry is passing through the maturity stage and it is inevitable to reduce the costs. The conventional mechanism of MF shows dependency on collector or staffs who work in the field level. Their productivity is crucial factor of efficiency by which cost of the MFIs can vary. Performance in client per collector is reflecting how efficient is each MFI based on their human resource. Savings per client are also indicating their superiority even in comparison among different sizes of MFIs.

Some of the major indicators which can differentiate SS among others are clients per collector, loan per client, savings per client, and percentage of loan client. This information clearly shows the efficiency of MFIs. 
Table 6. Efficiency comparison among different sizes of MFIs in Bangladesh

\begin{tabular}{|c|c|c|c|c|c|}
\hline \multirow[t]{2}{*}{ Indicator } & \multicolumn{2}{|c|}{$\begin{array}{l}\text { ASA \& BRAC (Large } \\
\text { MFIs with ICT) }\end{array}$} & \multicolumn{2}{|c|}{$\begin{array}{l}\text { PSS \& OF (Small } \\
\text { MFIs without ICT) }\end{array}$} & \multirow{2}{*}{$\begin{array}{c}\text { SafeSave (Small MFIs } \\
\text { with ICT) } \\
\text { SS }\end{array}$} \\
\hline & ASA & BRAC & PSS & OF & \\
\hline Number of clients per collector & 227 & 395 & 125 & 108 & 213 \\
\hline Loan per client (BDTK.) & 7052 & 5336 & 4500 & 7879 & 2794 \\
\hline Savings per client (BDTK.) & 1920 & 2258 & 1016 & 3295 & 3448 \\
\hline Percentage of loan clients & $86 \%$ & $71 \%$ & $77 \%$ & $69 \%$ & $54 \%$ \\
\hline Percentage of Savings clients & $14 \%$ & $29 \%$ & $23 \%$ & $31 \%$ & $46 \%$ \\
\hline
\end{tabular}

Table 6 points out SafeSave's performance over others. Collectors of SS are efficient closer to large MFIs with ICT whereas other small MFIs performances are remarkably low. Their loan per client is lowest in comparison with other types of MFIs. This performance indicator shows that they should rethink about the need of the clients. In the regression analysis it is proven that loan amount flexibility is one of the key influencing factor for customer satisfaction. By discussion with the clients, it reveals that clients of SS prefers savings product than loan product. It is proven by the percentage of savings clients' data. SS's $46 \%$ clients are savings clients which is higher than other types of MFIs. Their financial strength has proven by the figure savings per client.

\subsection{Distinct Characteristics of Safesave in Comparison to Other Type of MFIs}

In this part, we will examine why SS performance is higher in certain aspects showed above compared to the other samples and what makes them so unique.

\subsubsection{Target Clients}

In general, most of the MFIs in Bangladesh targets low-income group clients who are unable to get finance from the formal financial institutions. The sample MFIs also possesses similar characteristics except SS. SafeSave not only targets low income group but also people who living in slums in capital. Slums people are very risky in nature because of their temporary living in slums. Most of the slums are developed in unplanned way and people don't have any record as a resident of a place for certain time period. Despite of the vulnerable characteristics, SS targets slum dwellers and successful in nature. It is also proven by their occupation that most of them involve in small business though Bangladesh is an agricultural country. Other two groups of MFIs clients are rural based and agro based in nature.

\subsubsection{Group Orientation vs Individual Orientation}

Unlike conventional MFIs, SS deals with the client not as a group but as an individual basis. Group orientation usually works as an indirect pressure group in the case of loan approval, and repayment mechanism. Group oriented MFIs are using group as a method of lowering the risk. Each group member is liable for serious financial misconduct of other member. So, group members are monitoring each other. But SS works with clients individually because of floating characteristics of slum people. Slum dwellers are unable to recognize and guarantee each other.

\subsubsection{Product Focus}

There are two major categories of products in MF business. These are savings (deposit) and loan. Most of the MFIs are focusing on loan category, for example in our study, ASA, BRAC, Oriental Foundation and Polli Sheba Songsha all are explicitly depending on loan product. But SS considers savings product as their core product. SS's primary intention is to build such MFI which will encourage the poor people to change savings attitude. SafeSave's such concern can solve different problems of both MFIs and clients'.

SS has a rule for force savings against the loan. Normally one-third of clients loan balance should be there in clients' savings accounts. Though the other sample MFIs does not have any force savings policy as collateral, it is evident as an implicit principle. There are several other alternative procedures that MFIs can introduce to minimize the risk of loan rather than force savings policy.

\subsubsection{Diversity in Interests of Loan and Deposit}

Flexible savings scheme with $6 \%$ rate of interest makes the deposit product as a core product. Client can save any amount of money at any time. A client can draw maximum $\$ 6.25$ savings staying at home from collector. He 
or she needs to go to the branch office for any amount above that amount. In addition, long term savings plan is also available where clients get extra interest beyond the regular interest rate. Long term savings interest rates are $7 \%$ for 3 years, $8 \%$ for 5 years, $9 \%$ for 7 years, and $10 \%$ for 10 years. The condition of getting $6 \%$ normal interest is savings amount minimum $\$ 12.50$.

Regarding the loan product SS have different types of loan products. For example, one product namely p9 is interest free loan. Clients have to pay $\$ 2.5$ as an admission fee. The main purpose of this package is to give loan $\$ 62.50$ with the condition of 50\% loan amount must preserve in savings account. There is no interest rate but the client will pay 3\% loan disbursing fee for the whole term of loan life. If clients could pay the loan on time next time he will get loan of $\$ 125$. After paying the loan clients can draw the savings which can be used against the loan.

\subsubsection{Flexible Conditions}

SafeSave introduces flexible conditions in the case of deposit and withdrawal where a client can deposit and withdraw their money as many times as they like. Client can deposit as small as $\$ 0.2$ in one time transaction. Other samples MFIs have rules of onetime transaction in a weekly group meeting.

\subsubsection{Purpose of Loan}

SafeSave follows open funding policy without monitoring the purpose of the loan. A client can apply and get loan if he or she fulfill their loan conditions. All other MFIs in this study monitor loan purpose of a client. They approve the loan if the purpose is related to income generating activities (IGAs) such as farming, agriculture, fisheries etc. Because SS deals with client in different characteristics such as small business or daily wage workers, so the policy related to this matter is flexible.

\subsubsection{ICT Adoption}

All the staffs of large MFIs are using computers and mobile in their head office and branch office whereas Small MFIs like OF-PSS are not using computers at their branch office. Only in the head office small MFIs are using computers at a small scale. Large MFIs are using client, employee and accounting types of software for their operation but small MFIs (OF-PSS) have no experience of adopting any of those software. SS is the exception in this regard. Since December, 2009 SS have experience using ICT at all the level of operation starting from the field transaction to branch management and head office.

SS has computers and printers both in head office and branch office. Internet connection is available only in head office. SS does not have any payroll software.

\subsubsection{Human Resource and Education}

It is justifiable to give credit to the SS regarding competitive performance with large MFIs. Staff in SS must have secondary school certificate to be a collector according to their recruiting policy. Training is also another important aspect. They learn how to use PDA in the field transaction. This PDA stores past information of clients and it gives collector capability of immediate responses. And collectors can make the process faster. ICT certainly has positive impact in this regard. Around $44 \%$ clients of SS are savings client and it indicates their strength in the savings product and long term fund generation scope from this clients.

All new recruited collectors get training on the job as a mandatory basis. Usually the first time training duration is six (6) days. Branch managers are also qualified and trained to use the technology. And managers use this to ensure the accuracy of field operation. After adopting software, SS can input entry of transaction instantly and it took 5 to 6 days in previous time.

\subsubsection{Summary}

Table 7 shows the summary of the above analysis. Though CS of SS has proven insignificant in comparison with large MFIs, it has proven higher and significant in comparison with small MFIs. Flexibility of terms indicates conditions of MFIs in the issues such as interest on loan and force savings. In terms of loan amount flexibility, SS has better performer comparing to the small MFIs but in respect to the Large MFIs, SS have option to improve their performance. Despite SS is using ICT in the field level transaction, transaction process system in branch office and head office are not efficient. In the case of service time performance, it has proven slower. Clients of SS have positive outlook on recording system. Faith on recording is higher than large MFIs with ICT. While factors such as mobile money transaction and staff behavior, SS is not good performer. So the internal management systems should concentrate to human relation aspects in a cautious manner. 
Table 7. SafeSave's performance status in comparison of mean differences

\begin{tabular}{lcc}
\hline Criteria & Comparing to Large MFI with ICT & Comparing to Small MFI without ICT \\
\hline Customer satisfaction & Higher & Higher * \\
Flexibility on terms & Higher $* * *$ & Higher \\
Loan amount flexibility & Lower $* * *$ & Higher $* *$ \\
Service time & Slower & Slower * \\
Faith on recording & Higher $* * *$ & Low \\
Mobile money transfer & Lower & Lower *** \\
Staff behavior & Lower & Lower * \\
\hline
\end{tabular}

$* * *, * *, *$ represents significance at $1 \%, 5 \%$ and $10 \%$ level. Both higher and lower indicates performances of SafeSave is either higher or lower comparing to other types of MFIs.

\section{Discussion}

SafeSave aims to get competitive advantage on savings product mentioned above, with ICT. It is clear that product diversification and flexibility in products can be treated as reasons for competitive advantage. In MF business, ICT adoption can reduce the cost.

For example, ICT empowers collectors to manage more clients and MFIs can employ less collector. Eventually reduction of cost can increase the profit base and it in turn can increase its fund. As most of the MFIs belong to nonprofit making organization, this fund can be essentially useful for the benefits of customer, effect of ICT adoption is presented in figure 1. ICT can be an indispensable empowering tool even for small MFIs.

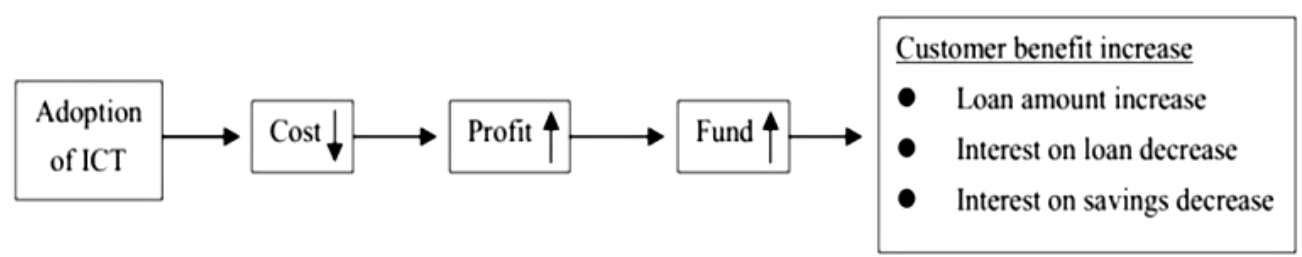

Figure 1. Effect of ICT adoption in microfinance business

As mentioned above, SS adopted ICT at the field level. Even though it is on the filed level, only SS, not the others, uses personal digital assistance (PDA) managed by collector. Collectors carry PDA (its cost is around $\$ 125)$ and move towards door to door for transaction purpose. Collectors input the transaction details into the PDA, later from the filed they came back to the branch office where inputted data are transferred to the database. This database update in the database of head office in weekly basis. The process can be described in the figure 2 .

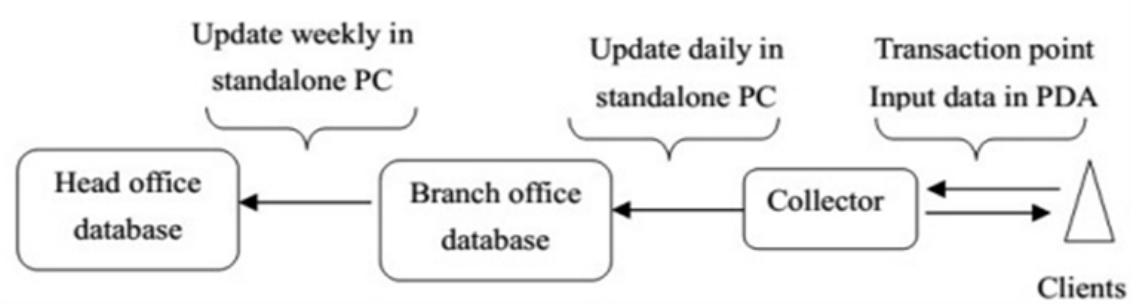

Figure 2. Transaction data collection procedure of SafeSave (SS)

This ICT introduction and usage ensures the need of proper training and development facilities for human resource development. All new recruited collectors get on-the-job training as a mandatory basis for ICT usage, 
and manager use ICT to ensure the accuracy of field operation. Adopting software can help them to input entry of transaction instantly.

But SS uses the technology in a limited way. They do neither have any payroll software nor networks among headquarters, branches, and fields. Table 8 shows possible scope of improvement and the expected effects.

Table 8. ICT usage and scope of improvement for SafeSave Bangladesh

\begin{tabular}{|c|c|c|c|}
\hline ICT usage issues & Status and advantage & Improvement scope & Expected effect \\
\hline $\begin{array}{l}\text { Field } \\
\text { transaction }\end{array}$ & $\begin{array}{l}\text { Used a PDA device with stored } \\
\text { data inside. Useful for } \\
\text { answering queries of clients } \\
\text { and input the transaction, } \\
\text { checking balance etc. }\end{array}$ & $\begin{array}{l}\text { Collectors are handling the } \\
\text { device. Mobile transaction can } \\
\text { be viable alternative and it's } \\
\text { essential to conduct feasibility } \\
\text { study. }\end{array}$ & $\begin{array}{l}\text { Cost can be decreased in } \\
\text { the long run and time of } \\
\text { transaction will be faster. }\end{array}$ \\
\hline $\begin{array}{l}\text { Real time } \\
\text { update }\end{array}$ & Not established & $\begin{array}{l}\text { Data can update in real time and } \\
\text { empower collector to take } \\
\text { decision options for loan } \\
\text { approval and savings withdrawal }\end{array}$ & $\begin{array}{l}\text { Prompt decision making } \\
\text { and efficient controlling } \\
\text { mechanism can be } \\
\text { developed. }\end{array}$ \\
\hline Network & No network established & $\begin{array}{l}\text { Network can improve } \\
\text { communication, decision } \\
\text { making, controlling and planning } \\
\text { of operational activities. }\end{array}$ & $\begin{array}{l}\text { Network establishment can } \\
\text { enhance monitoring and } \\
\text { collaboration activities. }\end{array}$ \\
\hline Software & $\begin{array}{l}\text { Internal accounting and } \\
\text { transaction software available. } \\
\text { It helps to check clients' and } \\
\text { human resources' performance }\end{array}$ & $\begin{array}{l}\text { Used vendor develop software } \\
\text { which needs to update based on } \\
\text { recent experiences. }\end{array}$ & $\begin{array}{l}\text { Customer and organization } \\
\text { friendly software } \\
\text { management systems can } \\
\text { be developed. }\end{array}$ \\
\hline
\end{tabular}

\section{Conclusion}

$\mathrm{SS}$ is a unique example of proving that a small firm can be efficient and gain confidence of customers. Their ICT adoption in field transaction, employee recruitment, training, and product orientation are some of the key success factors. On the other side, SS needs to be careful on monitoring the loan purpose and mobile money transfer issue. Furthermore, it is important for MF business in Bangladesh to address the issue of lowering the cost, improve the human relation and responsiveness with clients. Sustainable development of MF sector is real challenge for small MFIs as they have less fund, market share, and resources. ICT can empower even small firm like SS that proved competitive in MF industry and ICT helps to overcome big challenges mentioned above.

Clients of MFIs in Bangladesh are well accustomed to mobile phone and recent movement of mobile money transfer is also remarkable matter for MFIs to incorporate mobile for transaction. Mobile phone can work as an alternative communication because the infrastructure is very poor in Bangladesh. There are many parts of the country where proper roads and communication are not yet established. Through the mobile money transfer, MFIs can reduce cost, improve client management aspects and faster decision making. ICT have positive impact on efficiency and customer satisfaction which were found from the comparative case studies. Small MFIs can also adopt ICT and get competitive advantage. Lack of initiative, IT education, training facilities and infrastructure hinders ICT adoption for MFIs in Bangladesh.

\section{Contribution and Limitation}

Theoretically, this study contributes to the organizational transformation theories to better understand and incorporate issues related with ICT in developing country. Furthermore, various new factors that affect to the client satisfaction will certainly enrich marketing theories especially theories related to the consumer behavior.

This paper equally has important contributions to the directors or managers of MFIs where product and process modification considering customers feedback has proven essential issue in current state of MF industry. ICT application and possible breakthrough is indicated as a dimensional issue by which MFIs can achieve competitive advantage, customer satisfaction, better outreach and sustainability in the long run.

This study has limitations in several areas, for example data unavailability of MF sector in Bangladesh, and insufficient fund for conducting independent research. There are several methods to infer the situation. For 
example, through secondary reliable data source we can figure out the effect of various factors in changing organization but there is no such database available of MF in Bangladesh. Despite the limitations, this research attempted to incorporate both quantitative and qualitative analysis and conducted several field visits and interviews with practitioners and clients, which all made it possible to reveal the existing situation, ICT introduction and customer satisfaction of MF sector in Bangladesh.

\section{References}

Afrin, S., Islam, N., \& Ahmed, S. U. (2008). A Multivariate Model of Micro Credit and Rural Women Entrepreneurship Development in Bangladesh. International Journal of Business and Management, 3(8), 169-185.

Ahmed, S. (2009). Microfinance Institutions in Bangladesh: achievements and challenges. Managerial Finance, 35(12), 999-1010. http://dx.doi.org/10.1108/03074350911000052

Amin, R., Becker, S., \& Bayes, A. (1998). NGO-promoted microcredit programs and women's empowerment in rural Bangladesh: Quantitative and qualitative evidence. The Journal of Developing Areas, 32, 221-236.

Attali, J. (2000). A Market Solution to Poverty: Microfinance and the Internet. New Perspectives Quarterly, 17(1), 31-33. http://dx.doi.org/10.1111/0893-7850.00235

Au, Y. A., \& Kauffman, R. J. (2008). The economics of mobile payments: Understanding stakeholder issues for an emerging financial technology application. Electronic Commerce Research and Applications, 7(2), 141-164. http://dx.doi.org/10.1016/j.elerap.2006.12.004

Avkiran N. (1994). Developing an instrument to measure customer service quality in branch banking. International Journal of Bank Marketing, 12(6), 10-18. http://dx.doi.org/10.1108/02652329410063223

Beck, T., Demirgüç-Kunt, A., \& Honohan, P. (2009). Access to Financial Services: Measurement, Impact, and Policies. The World Bank Research Observer. http://dx.doi.org/10.1093/wbro/lkn008

Bhatt, N., \& Tang, S. (2001). Delivering microfinance in developing countries: Controversies and policy perspectives. Policy Studies Journal, 29, 319-333. http://dx.doi.org/10.1111/j.1541-0072.2001.tb02095.x

Bhattacherjee, A. (2001). Understanding Information Systems Continuance: An Expectation confirmation Model. MIS Quarterly, 25(3), 351-370. http://dx.doi.org/10.2307/3250921

Chang, Y. (2002). Dynamics of banking technology adoption. An application to Internet Banking Working Paper, University of Warwick.

Cull, R., Demirgüç-Kunt, A., \& Morduch, J. (2009). Microfinance Meets the Market. Journal of Economic Perspectives, 23(1), 167-192. http://dx.doi.org/10.1257/jep.23.1.167

Dailey, J. (2005). Microfinance needs a common platform for access to capital and scalable operational systems. In S. Mathison (Ed.), Electronic Banking with the Poor: Increasing the Outreach and Sustainability of Microfinance through ICT Innovation. Brisbane, Australia: Foundation for Development Cooperation.

Diniz, E., Birochi, R., \& Pozzebon, M. (2011). Triggers and barriers to financial inclusion: the use of ICT based branchless banking in an Amazon county. Electronic Commerce Research and Applications. http://dx.doi.org/10.1016/j.elerap.2011.07.006

Diniz, E., Pozzebon, M., \& Vargas, G. (2008). Banking technology to scale microfinance: the case of correspondent banking in Brazil. International Conference on Information Systems, December, Paris, France.

Dowla, A., \& Alamgir, D. (2003). From Microcredit to Microfinance: Evolution of Savings Products by MFIs in Bangladesh. Journal of International Development, 15, 969-988. http://dx.doi.org/10.1002/jid.1032

Godquin, M. (2004). Microfinance Repayment Performance in Bangladesh: How to Improve the Allocation of Loans by MFIs. World Development, 32(11), 1909-1926. http://dx.doi.org/10.1016/j.worlddev.2004.05.011

Goetz, A. M., \& Rina, S. G. (1996). Who Takes the Credit? Gender, Power, and Control over Loan Use in Rural Credit Programs in Bangladesh. World Development, 24, 45-63. http://dx.doi.org/10.1016/0305-750X(95)00124-U

Hannan, T. H., \& M. McDowell, J. (1984). The determinants of technology adoption, the case of the banking firm. Rand Journal of Economics, 54(3), 328-335. http://dx.doi.org/10.2307/2555441

Hashemi, S. M., Schuler, S. R., \& Ann, P. R. (1996). Rural Credit Programs and Women's Empowerment in Bangladesh. World Development, 24, 635-53. http://dx.doi.org/10.1016/0305-750X(95)00159-A 
Haynes, M., \& Thompson, S. (2000). The productivity impact of IT deployment: An empirical evaluation of ATM introduction. Oxford Bulletin of Economics and Statistics, 62(5), 631-643. http://dx.doi.org/10.1111/1468-0084.00192

Islam, M. T., \& Natori, T. (2012). A study on the factors affecting diffusion of microfinance in Bangladesh-Quantitative approach by applying BASS model. International Journal of Japan Association for Management Systems, 4(1), 77-83.

Kauffman, R. J., \& Riggins, F. J. (2012). Information and communication technology and the sustainability of microfinance. Electronic Commerce Research and Applications. http://dx.doi.org/10.1016/j.elerap.2012.03.001

Keniston, K. (2003). IT for the masses: Hype or hope? Working paper. http://www.mit.edu/people/kken/PAPERS/EPW paper.html

Khandker, S. R., \& World Bank. (1998). Fighting poverty with microcredit: experience in Bangladesh. Oxford New York, NY: University Press.

Lapenu, C., \& Dorothée P. (2006). Handbook for the analysis of the governance of microfinance institutions. IFAD website. http://www.ifad.org/ruralfinance/pub/handbook.pdf (accessed October 31, 2012).

Lee, S. M., Kim, J. Y. C., \& Lee, S. G. (2009). Effects of IT knowledge and media selection on operational performance of small firms. Small Business Economics, 32(3), 214-257. http://dx.doi.org/10.1007/s11187-007-9095-5

Lendrevie, J., \& Lindon, D. (1997). Mercator (5th ed.). Paris: Dalloz.

Lyman, T., Pickens, M., \& Porteous, D. (2008). CGAP website. Retrieved from http://www.cgap.org/publications/all?\&\&\&year(value)(year)=2008\&page=2

Menkhoff, L., Neuberger, D., \& Rungruxsirivorn, O. (2012). Collateral and its substitutes in emerging markets' lending. Journal of Banking \& Finance, 36(3), 817-834. http://dx.doi.org/10.1016/j.jbankfin.2011.09.010

Mersland, R., \& Strom, R. O. (2009). Performance and corporate governance. Journal of Banking \& Finance, 33(4), 662-669. http://dx.doi.org/10.1016/j.jbankfin.2008.11.009

Microcredit Regulatory Authority. (2010). NGO-MFIs in Bangladesh. Dhaka: Microcredit Regulatory Authority.

Mosley, P., \& David, H. (1998). Microenterprise finance: Is there a conflict between growth and poverty alleviation. World Development, 26, 783-790. http://dx.doi.org/10.1016/S0305-750X(98)00021-7

Murray, I., \& Lynch, E. (2003). What Do Microfinance Customers Value. Retrieved from http://www.swwb.org/sites/default/files/pubs/en/what_do_microfinance_customers_value_e.pdf

Othman, A., \& Owen, L. (2001). The multi dimensionality of Carter model to measure customer service quality (SQ) in Islamic banking industry: a study in Kuwait finance House. International Journal of Islamic Financial Services, 3(1).

Parasuraman, A., Zeithaml, V. A., \& Berry, L. L. (1985). A Conceptual Model of Service Quality and Its Implications for Future Research. Journal of Marketing, 49, 41-50. http://dx.doi.org/10.2307/1251430

Schuler, S. R., \& Hashemi, S. M. (1994). Credit programs, women's empowerment, and contraceptive use in rural Bangladesh. Studies in Family Planning, 25, 65-76. http://dx.doi.org/10.2307/1251430

Schuler, S. R., Hashemi, S. M., \& Badal, S. H. (1998). Men's violence against women in rural Bangladesh: Undermined or exacerbated by microcredit programmes. Development in Practice, 8, 148-157. http://dx.doi.org/10.1080/09614529853774

Schuler, S. R., Hashemi, S. M., \& Riley, A. P. (1997). The influence of women's changing roles and status in Bangladesh's fertility transition: Evidence from a study of credit programs and contraceptive use. World Development, 25, 563-575. http://dx.doi.org/10.1016/S0305-750X(96)00119-2

Silva, S. (2002). Quantum leap: microcredit boosted by technology. Microcredit Americas Magazine, 32-35.

Verhoef, P. (2003). Understanding the effect of customer relationship Management efforts on customer retention and customer share development. Journal of Marketing, 67, 30-45. http://dx.doi.org/10.1509/jmkg.67.4.30.18685

Wenham, A. (2004). SafeSave website. Retrieved from http://www.safesave.org/publications 


\section{Copyrights}

Copyright for this article is retained by the author(s), with first publication rights granted to the journal.

This is an open-access article distributed under the terms and conditions of the Creative Commons Attribution license (http://creativecommons.org/licenses/by/3.0/). 